\title{
COMMENTS
}

\section{Patronage Dismissals: Constitutional Limits and Political Justifications}

In 1971, a newly elected Democratic governor of Pennsylvania fired some 2,000 state employees who were unprotected by civil service laws. The dismissed employees, all Republicans who had obtained their jobs through Republican sponsorship or patronage, sought an injunction against the mass firings on the ground that political affiliation is an impermissible basis for discharge. ${ }^{1}$

On a smaller scale, Democrat Daisy Alomar, who had worked for the City of Rochester for more than two years as a social worker, was fired from her job in 1970 because she refused to accede to the requests of her supervisors that she shift her political affiliation to the Republican Party. ${ }^{2}$

In 1970 a Republican was appointed by the governor of Illinois to fill the unexpired term of the late Secretary of State, a Democrat. The new appointee dismissed 1,946 of some 4,000 persons employed by his office; all of them held non-civil service positions as building employees, clerical workers, license examiners, and the like. The discharged employees filed an action against the Secretary of State claiming that they had been dismissed because of their refusal to join or support the Republican Party. ${ }^{3}$

In the first two of these patronage dismissal cases, courts upheld the firings without considering whether dismissal of non-policy-making government workers for political affiliation is necessary to satisfy any governmental interests. In the third, the court found the practice, although defended in the name of democratic tradition, "at war with the deeper traditions of democracy embodied in the first amendment,"4 and held that the governmental interests asserted in defense of the practice did not justify it.

Despite the recent development of constitutional doctrine narrowing the scope of permissible governmental discretion over the distribution

1 American Fed'n of State, County \& Municipal Employees v. Shapp, 443 Pa. 527, 280 A.2d 375 (1971).

2 Alomar v. Dwyer, 447 F.2d 482 (2d Cir. 1971), cert. denied, 404 U.S. 1020 (1972).

3 Illinois State Employees Union v. Lewis, 473 F.2d 561 (7th Cir. 1972), cert. denied, 410 U.S. 928, 943 (1973).

4 Id. at 576 . 
of public benefits, ${ }^{5}$ the Supreme Court has twice refused to review the constitutionality of patronage dismissals. ${ }^{6}$ Nevertheless, because of the confused and conflicting decisions in the lower courts, and the serious constitutional issues raised by this form of public personnel administration, authoritative resolution cannot be indefinitely postponed.

This comment examines the constitutionality of patronage dismissals. ${ }^{7}$ First, the patronage system is shown to condition public employment on a restriction of speech and association and to treat patronage employees in a discriminatory fashion-findings that require the system to be declared unconstitutional unless it is justified by important governmental interests. Next, the two principles used by the courts to avoid examination of governmental interests-the right-privilege distinction and the concept of waiver of constitutional rights-are shown to be inadequate and in conflict with current constitutional doctrine. Finally, the comment discusses and evaluates the possible governmental interests served by the patronage system of employment. It is not diffcult to demonstrate that accepted constitutional principles compel careful scrutiny of governmental interests in the patronage system, but examination of those interests reveals that the courts face an extremely difficult task in determining whether the restrictions on individual rights imposed by the patronage system are justifiable.

\section{The Prima Facie Unconstitutionality of Patronage Dismissals}

Discharge of public employees for political affiliation affects their constitutional rights in two ways. It indirectly abridges their right of

5 See, e.g., Morrissey v. Brewer, 408 U.S. 471,493 (1972); Graham v. Richardson, 403 U.S. 365, 374 (1971); Bell v. Burson, 402 U.S. 535, 539 (1971); Goldberg v. Kelly, 397 U.S. 254, 262 (1970); Shapiro v. Thompson, 394 U.S. 618, 627 n.6 (1969); Pickering v. Board of Educ., 391 U.S. 563,568 (1968); Sherbert v. Verner, 374 U.S. 398, 404 (1963).

6 See notes 2 \& 3 supra.

7 Although the discussion focuses on the constitutional implications of dismissals from public employment on a partisan basis, it must be noted that public employment is only one form of political patronage. Loyal party supporters are also rewarded with jobs in private industries with which the government does business; public contracts for defense projects, highways, buildings, and insurance; lucrative franchises for the wide range of supplies that the government needs; tax abatements and racing dates; judgeships and attendant courtroom patronage such as receiverships, trusteeships, and refereeships; improved public services for favored wards; and assistance in navigating "the maze of federal and state bureaucracy to obtain the far-ranging services to which they are entitled." M. Tolchin \& S. Tolchin, To THE VICTOR ... (1971). Dismissals from public jobs are here focused upon because they provide the clearest and most easily proven examples of government largesse explicitly denied because of-or conditioned upon-political affiliation or expression. Although the other forms of patronage are not specifically treated here, much of the analysis of employment dismissals is applicable to the other types of patronage. 
association, and it establishes distinctions based upon political allegiance that deny patronage employees equal protection of the laws. Both effects require the courts to examine the purposes of the patronage employment system, and to declare it unconstitutional unless it is found to serve important governmental interests.

\section{A. Freedom of Association and the Doctrine of Unconstitutional Conditions}

Although nowhere expressly mentioned in the Constitution, freedom of association is, beyond all doubt, guaranteed by the first and fourteenth amendments. ${ }^{8}$ The right of individuals to associate for the advancement of political beliefs has been specifically recognized by the Supreme Court ${ }^{9}$ and held to "rank among our most precious freedoms." The affirmative freedom to associate for the collective advocacy of ideas implies freedom from coerced political affiliation; both freedoms are "protected not only against heavy-handed frontal attack, but also from being stifled by more subtle governmental interference."10 Although constitutional protection of freedom of association is not absolute ${ }^{11}$ and government action that may have the effect of curtailing that freedom is subject to the closest scrutiny, ${ }^{12}$ such restrictions must be justified by extraordinary circumstances or important public needs, and even then the limiting regulation or action must be drawn with narrow specificity. ${ }^{13}$

Patronage employees are not protected by statute, and there is no constitutional right to public employment. It is conceded, therefore, that patronage employees serve at the pleasure of the appointing officer and may be discharged without cause. The Constitution, however, pro-

8 United States v. Robel, 389 U.S. 258, 263 (1967); NAACP v. Alabama, 357 U.S. 449 (1958); Dejonge v. Oregon, 299 U.S. 353 (1937).

0 Williams v. Rhodes, 393 U.S. 23, 30 (1968).

10 Bates v. City of Little Rock, 361 U.S. 516, 523 (1960). See also Unithd Mine Workers of America, Dist. 12 v. Illinois State Bar Ass'n, 389 U.S. 217, 222 (1967); Louisiana v. NAACP, 366 U.S. 299, 297 (1961). In United States v. Robel, 389 U.S. 258, 263 (1967), the Court directly reaffirmed that "the exercise of an individual's right of association ... is protected by the provisions of the First Amendment."

11 United States Civil Serv. Comm'n v. National Ass'n of Letter Carriers, 413 U.S. 548, 567 (1973); cf. Chaplinsky v. New Hampshire, 315 U.S. 568, 571 (1942). See also Cox v. Louisiana, 379 U.S. 536, 554 (1965); American Communications Ass'n v. Douds, 339 U.S. 382,394 (1950).

12 See NAACP v. Alabama, 357 U.S. 449, 460-61 (1958).

13 See United States v. Robel, 389 U.S. 258, 265 (1967); NAACP v. Button, 371 U.S. 415, 432-33 (1963); Shelton v. Tucker, 364 U.S. 479, 488 (1960); Cantwell v. Connecticut, 310 U.S. 296, 311 (1940); Note, The First Amendment Overbreadth Doctrine, 83 HaRv. L. Rev. 844 (1970). 
hibits government action that restricts an individual's exercise of fundamental rights unless such action is necessary to promote a compelling governmental interest or there is a valid waiver. An individual's right to associate politically is protected not only from direct infringement, but also from indirect infringement, such as the conditioning of government benefits on restriction or invalid waiver of that right. This latter protection, sometimes called the "doctrine of unconstitutional conditions," 14 has found expression in judicial opinions dealing with diverse government benefits. ${ }^{15}$ Justice Sutherland articulated the es-

14 See Bruff, Unconstitutional Conditions Upon Public Employment: New Departures in the Protection of First Amendment Rights, 21 Hastincs L.J. 129 (1969); French, Unconstitutional Conditions: An Analysis, 50 Gro. L.J. 234 (1961); Van Alstyne, The Demise of the Right-Privilege Distinction in Constitutional Law, 81 HARv. L. REv. 1439 (1968); Note, Unconstitutional Conditions, 73 HARv. L. REv. 1595 (1960); Note, Another Look at Unconstitutional Conditions, 117 U. PA. L. REv. 144 (1968).

Van Alstyne notes, supra at 1447, that the doctrine of unconstitutional conditions "provides no protection against a regulation which is simply unreasonable or even outrageous in that it has no reasonable connection with any legitimate public purpose ...." The condition complained of must be specially unreasonable in the sense that it impairs an explicit guarantee in the Constitution. The traditional doctrine of unconstitutional conditions has been applied only where there is an infringement of an expressly guaranteed constitutional right, but it is difficult to understand why it has not also been applied to implied rights. See id. at 1447 n.32. Although it may be argued that the freedom of association is an implied guarantee (though not of the degree of implication as, for example, the "right to travel"), a persuasive argument may be made for considering it "explicit." Freedom of association, especially political association, is in some circumstances indistinguishable from freedom of speech, the right which has most often been protected by the doctrine of unconstitutional conditions. Restrictions upon a patronage employee's freedom to associate cast an obvious chill on his freedom to speak openly, since his job security depends on not only his associational tie but also his refraining from expressing opinions critical of his superiors or their party. Therefore, even if the rather pointless distinction between explicit and implicit rights is embodied in the doctrine, the freedom of political association as infringed in the patronage context merits protection. See Note, $A$ Constitutional Analysis of the Spoils System-The Judiciary Visits Patronage Place, 57 IowA L. REv. 1320, 1332-33 (1972); cf. Griswold v. Connecticut, 381 U.S. 479,483 (1965). If freedom of association were considered only an implied constitutional right, its indirect infringement would still: be prohibited by the more liberal formulation of the theory, known as the "doctrine of indirect effects." See Van Alstyne, supra, at 1449-51.

15 E.g., Graham v. Richardson, 403 U.S. 365, 374 (1971); Connell v. Higginbotham, 403 U.S. 207 (1971) (loyalty oath); Shapiro v. Thompson, 394 U.S. 618, 627 n.6 (1969) (welfare benefits); Sherbert v. Verner, 374 U.S. 398 (1963) (striking down discriminatory unemployment compensation statute that denied benefits to Seventh Day Adventist who refused to work on Saturday: "liberties of religion and expression may [not] be infringed by the denial of or placing of conditions upon a benefit or privilege.") Id. at 404 (footnote omitted); Speiser v. Randall, 357 U.S. 513 (1958) (reversing denial of a tax exemption to one who would not affirm nonadvocacy of violent overthrow of the government: "a constitutional prohibition cannot be transgressed indirectly by the creation of a statutory presumption any more than it can be violated by direct enactment . . . . It can only result in a deterrence of speech which the Constitution makes free.' "Id. at 526, quoting from Bailey v. Alabama, 219 U.S. 219, 239 (1911)). Cases in which the principle has been applied to denials of public employment are collected in Perry v. Sindermann, 408 U.S. 593, 597 (1972). 
sence of the doctrine in Frost \& Frost Trucking Co. v. Railroad Commission:

It would be a palpable incongruity to strike down an act of state legislation which, by words of express divestment, seeks to strip the citizen of rights guaranteed by the federal Constitution, but to uphold an act by which the same result is accomplished under the guise of a surrender of a right in exchange for a valuable privilege which the state threatens otherwise to withhold. It is not necessary to challenge the proposition that, as a general rule, the state, having power to deny a privilege altogether, may grant it upon such conditions as it sees fit to impose. But the power of the state in that respect is not unlimited, and one of the limitations is that it may not impose conditions which require the relinquishment of constitutional rights. If the state may compel the surrender of one constitutional right as a condition of its favor, it may, in like manner, compel a surrender of all. It is inconceivable that guarantees embedded in the Constitution of the United States may thus be manipulated out of existence. ${ }^{16}$

In the patronage context, it must first be ascertained whether the employee's job is a benefit of the type that cannot be subjected to an unconstitutional condition. The courts' traditional negative answer cannot be justified any longer by labeling a public job as merely a privilege deserving no protection. ${ }^{17}$ The rejection of the right-privilege distinction has been underscored most recently in Board of Regents $v$. Roth ${ }^{18}$ and Perry v. Sindermann. ${ }^{19}$ Although those cases are most important for their statement of the principles underlying the grant or denial of procedural due process, their teachings on unconstitutional conditioning of public employment are particularly relevant to the patronage dismissal. Roth and Perry together affirm that, regardless of whether an individual's interest in government employment is of the kind that must be accorded the protections of procedural due process, the interest may not be unconstitutionally conditioned.

Both Roth and Perry dealt with dismissals of nontenured teachers ${ }^{20}$ from the public school system. The essence of the Roth opinion is the rule that a determination of whether procedural due process is demanded in any particular situation requires examination of the nature, rather than the weight, of the interests at stake. Only interests involving

16271 U.S. 583, 593-94 (1926) (invalidating a state regulation imposing common carrier liability on private trucking companies).

17 For a discussion of this traditional approach, see text and notes at notes 51-71 infra.

18408 U.S. 564 (1972).

19408 U.S. 593 (1972).

20 For a discussion of the question of de facto tenure in Perry, see note 23 infra. 
"life, liberty, or property" are so protected. Patronage employment does not qualify as "life, liberty, or property" under the fourteenth amendment as construed in Roth, ${ }^{21}$ and therefore does not require procedural protections. Nevertheless, Roth indicates only that such employment is subject to summary termination without a showing of cause; the case does not imply that the government may discharge an employee for any reason it may choose.

Roth's companion case, Perry v. Sindermann, states expressly what the former opinion only implies. While in Roth there was no allegation before the Court of an impermissible basis for the discharge, ${ }^{22}$ Perry did consider such an allegation. ${ }^{23}$ The Court was unanimous in

21 Roth defined "liberty" broadly to include the freedom to enjoy the many benefits essential to the orderly pursuit of happiness and thus determined that the decision to discontinue employment could implicate interests in liberty in some circumstances, such as (1) where dismissal, accompanied by charges of dishonesty or immorality, impugns the employee's reputation or integrity (citing Wisconsin v. Constantineau, 400 U.S. 433, 437 (1971); Wieman v. Updegraff, 344 U.S. 183, 191 (1952)) or (2) where dismissal so stigmatizes the employee that a range of employment alternatives is foreclosed (citing Joint Anti-Fascist Refugee Comm. v. McGrath, 341 U.S. 123, 185 (1951) (Jackson, J., concurring)). 408 U.S. at 573-74; cf. Willner v. Committee on Character, 373 U.S. 96, 103 (1963); Schware v. Board of Bar Examiners, 353 U.S. 232, 238 (1957). In such cases, due process would require notice and hearing to allow the employee to attempt to refute the charges and clear his name, although not necessarily to gain reinstatement. No such circumstances, however, attend the patronage dismissal. The patronage employee is fired simply because he belongs to the defeated party; the factor that got him hired becomes the factor that gets him fired. The dismissal reflects on neither his honesty nor his morality, nor is he stigmatized so as to foreclose alternative nonpatronage employment. Therefore, no due process interests in "liberty" are involved.

Roth also recognized the broad scope of modern "property" interests, including the ability of persons to have such interests in government largesse. It is settled that interests in public employment held under tenure provisions, Slochower v. Board of Educ. 350 U.S. 551 (1956), or contract, Wieman v. Updegraff, supra, or implied contract, Connell v. Higginbotham, 403 U.S. 207, 208 (1971), merit procedural protection from the arbitrary or unreasonable exercise of government power. But the controlling attribute of a "property" interest is the legitimate claim of entitlement created and defined, not by the Constitution, but by substantive state law, local rules, and understandings. A "property" interest is more than a unilateral expectation of a benefit. Given the absence of statutes or contracts covering the patronage employee's term of appointment, the substantive rules and understandings in this context are the long-standing political traditions of the spoils systems. At most, there is some implicit understanding that the job very probably, though not certainly, will end when the patron or his party falls out of power. Despite the preference of the dissenting Justices Douglas, Brennan, and Marshall for a considerably broader view of the kinds of interests requiring due process protection, 408 U.S. at 579-92, the patronage employee's interest in his job does not rise to the level of "property" within the Roth majority"s definition. Without a "legitimate claim of entitlement" to his job, the patronage employee is subject to dismissal without notice or hearing.

22408 U.S. at 574.

23408 U.S. 593, 595 (1972). A second issue treated in the case concerned the relevance of the plaintiff's lack of formal contractual or tenure security to his procedural due process 
deciding that the plaintiff's inability ultimately to establish a property interest in his job would not defeat a claim that his dismissal resulted from the imposition of unconstitutional conditions on his freedom of speech. Perry declares that even a public servant with no constitutional or statutory right to his job cannot be dismissed simply for exercising his first amendment rights, even though he may be summarily dismissed with no hearing or statement of reasons. ${ }^{24}$ Expressly reaffirming $^{25}$ Shelton v. Tucker ${ }^{26}$ and Keyishian v. Board of Regents, ${ }^{27}$ Justice Stewart explained the Court's holding:

For at least a quarter century, this Court has made clear that even though a person has no "right" to a valuable governmental benefit and even though the government may deny him the benefit for any number of reasons, there are some reasons upon which the government may not rely. It may not deny a benefit to a person on a basis that infringes his constitutionally protected interests-especially, his interest in freedom of speech. For if the government could deny a benefit to a person because of his constitutionally protected speech or associations, his exercise of those freedoms would in effect be penalized and inhibited. . . . Such interference with constitutional rights is impermissible. ${ }^{28}$

Thus public employment, even of nontenured employees, is a benefit that triggers the unconstitutional condition analysis.

A condition that requires surrender of freedom of speech or asso-

claim. The Court rejected, 408 U.S. at 599, the Fifth Circuit's suggestion, 430 F.2d 944 (1972), that the plaintiff might have a due process claim simply because he asserted that his dismissal was based on his constitutionally protected conduct. Justice Stewart noted, however, that the presence or absence of a due process claim was irrelevant to the plaintiff's first amendment claim. Therefore, any attempt to distinguish Perry from the patronage context (where even a claim of de facto entitlement would be difficult to raise seriously), on the grounds that a property interest might have been found in Perry, must fail. The two claims, in the opinion of the majority, are distinct. (Justices Douglas, Brennan, and Marshall dissented from that proposition on grounds similar to those reflected in the Fifth Circuit's suggestion. See note 21 supra.) See Russo v. Central School Dist. No. 1, 469 F.2d 623, 628 n.6 (2d Cir. 1972), where the court found it unnecessary to get to the discharged nontenured teacher's procedural due process claim since it could grant relief on her first amendment claim.

24408 U.S. at $596-98$.

$25 I d$, at 598.

26364 U.S. 479 (1960) (state statute compelling every teacher to file annually an affdavit listing all memberships in, and contributions to organizations held invalid as overbroad in impairing the freedom of association of teachers hired on a year-to-year basis).

27385 U.S. 589 (1967) (invalidating the New York Feinberg Law as unconstitutionally overbroad and rejecting the premise that "public employment ... may be conditioned upon the surrender of constitutional rights which could not be abridged by direct government action.') Id. at 605 . For a description of the law, see note 95 infra.

28408 U.S. at 597. 
ciation is generally impermissible. ${ }^{29}$ Although the Supreme Court has never directly held that a criterion such as political party affiliation creates this type of condition, recent dicta in Williams $v$. Rhodes ${ }^{30}$ clearly indicates that the Court would so hold. In addition to the statements in the Williams case, the Court, in dicta attacking the rightprivilege distinction, has repeatedly drawn on political party affiliation as an example of an impermissible restriction on eligibility for public benefits. In United Public Workers $v$. Mitchell, the Court stated: "Appellants urge that federal employees are protected by the Bill of Rights and that Congress may not "enact a regulation providing that no Republican, Jew or Negro shall be appointed to federal office' ... . None would deny such limitations on Congressional power . ..."31 In Cafeteria Workers Union v. McElroy, the Court approved this statement, adding: "We may assume that [the employee] could not constitutionally have been excluded from the Gun Factory if the announced grounds for her exclusion had been patently arbitrary or discriminatory-that she could not have been kept out because she was a Democrat or a Methodist." 32

In Schware v. Board of Bar Examiners, the Court noted that: "A State can require high standards of qualification, such as good moral character, or proficiency in its law, before it admits an applicant to the bar, but any qualification must have a rational connection with the applicant's fitness or capacity to practice law .... Obviously an applicant could not be excluded merely because he was a Republican or a Negro or a member of a particular church."33 In Connell v. Higginbotham, Justice Marshall, concurring with the Court's decision to uphold part of a loyalty oath required of state employees, observed that: "Such a forward-looking, promissory oath of constitutional support does not in my view offend the First Amendment's command that the grant or denial of governmental benefits cannot be made to turn on the political viewpoints or affiliations of a would-be beneficiary."34

Most recently, in United States Civil Service Commission v. National Association of Letter Carriers, ${ }^{35}$ the Supreme Court, in reviewing.Hatch Act restrictions on the political activities of federal employees, said that "[t]he problem in any case is to arrive at a balance between the interest of the [employee], as a citizen, ... . and the interest of the [government],

29 See text at notes 8-13 supra.

30393 U.S. 23, 30-34 (1968).

31330 U.S. 75, 100 (1947).

32367 U.S. 886, 898 (1961).

33353 U.S. 232, 239 (1957).

34403 U.S. 207, 209 (1971) (Marshall, J., concurring).

35413 U.S. 548 (1973). 
as an employer . ..."36 In finding that the particular restrictions in that case were justified by the governmental interests involved, the Court was careful to note: "The restrictions so far imposed on federal employees are not aimed at particular parties, groups, or points of view, but apply equally to all partisan activities of the type described. They discriminate against no racial, ethnic, or religious minorities. Nor do they seek to control political opinions or beliefs, or to interfere with or influence anyone's vote at the polls." 37

Examined in this constitutional framework, patronage dismissals plainly restrict activities protected by the first amendment. Whether the government dismisses an employee for his political affiliation, demands that an employee change his loyalty to serve the political cause of the current regime, or rejects a qualified applicant because his political loyalties are not suitable, the effect is the same: a price is placed on the exercise of constitutionally protected rights, and the government's interest in exacting that price must be carefully examined. ${ }^{\mathbf{3 8}}$ Freedom of association and speech are restricted both when an employee is forced to give active support to one political party, ${ }^{30}$ and when employment is conditioned on the suspension of activities in favor of one political party. The right to remain passive, unaffiliated, or silent in the face of an unjustifiable demand for speech, active support, or financial contribution is as much protected by the first amendment as the right to speak, assemble, and affiliate freely in the face of an unjustifiable demand for silence. ${ }^{40}$ To paraphrase Justice Jackson, ${ }^{41}$ if there is any fixed star in our constitutional constellation, it is that no government official may prescribe what is orthodox in politics or other matters of opinion, or force citizens to confess by word or act their faith therein by conditioning public benefits thereon.

\section{B. An Alternative Approach: Equal Protection}

Dismissal of public employees because of party affiliation can also be characterized as a de facto legislative classification that deprives em-

$36 I d$. at 564, quoting from Pickering v. Board of Educ. 391 U.S. 563, 568 (1968).

37 Id. at 564.

38 Cf. Johnson v. Branch, 364 F.2d 177 (4th Cir. 1966), cert. denied, 385 U.S. 1003 (1967); Bomar v. Keyes, 162 F.2d 136 (2d Cir.), cert. denied, 332 U.S. 825 (1947). See also Bogacki v. Board of Supervisors of Riverside County, 5 Cal. 3d 771, 784, 489 P.2d 537, 545, 97 Cal. Rptr. 657, 665 (197I) (Tobriner, J., dissenting), cert. denied, 405 U.S. 1030 (1972); Bagley v. Washington Township Hosp. Dist., 65 Cal. 2d 449, 421 P.2d 409, 55 Cal. Rptr. 401 (1966); Comment, Due Process for Public Employees, 12 Santa Crara Law. 599 (1972).

39 See Shakman v. Democratic Organization of Cook County, 435 F.2d 267 (7th Cir. 1970), cert. denied, 402 U.S. 909 (1971), modified on remand, 856 F. Supp. 1241 (N.D. Ill. 1972).

40 Russo v. Central School Dist. No. 1, 469 F.2d 623 (2d Cir. 1972).

41 West Virginia State Bd. of Educ. v. Barnette, 319 U.S. 624, 642 (1943). 
ployees of equal protection of the laws. The government is not obligated to create and distribute benefits to the public; once it chooses to do so, however, the distribution may not be based on arbitrary or discriminatory classifications. ${ }^{42}$ Any distribution scheme that withholds public benefits from persons who do not, or will not, meet an unjustifiable criterion of eligibility is a constitutionally impermissible classification.

The Supreme Court has found it unnecessary to "pause to consider whether an abstract right to public employment exists. It is sufficient to say that constitutional protection does extend to the public servant whose exclusion pursuant to a statute is patently arbitrary or discriminatory." 43 Just as governmental largesse cannot validly be withheld from those of a certain race or from those professing a particular religious belief,44 it cannot be withheld from those who refuse to comply with terms of employment that are discriminatory and serve no. substantial governmental interest. ${ }^{45}$

A system permitting patronage dismissals may also violate equal protection by creating an invidious statutory classification that protects some public employees-those under a civil service scheme-from improper discharge but denies that protection to others. As to some toplevel, nonmerit employees, the government will be able to show sufficient justification for denying them statutory protection and dismissing them for political reasons. ${ }^{46}$ The question remains, however, whether the lack of coverage for certain members of the government work force, such as maintenance employees, clerical workers, and the like, can also be justified. ${ }^{47}$

42 See generally Tussman \& ten Broek, The Equal Protection of the Laws, 37 CALIF. L. REv. 341 (1949).

43 Wieman v. Updegraff, 344 U.S. 183, 192 (1952) (invalidating loyalty oath for public employees on overbreadth grounds).

44 See Torcaso v. Watkins, 367 U.S. 488 (1961).

45 See Slochower v. Board of Educ., 350 U.S. 551, 555 (1956). See generally Harper v. Virginia Bd. of Elections, 383 U.S. 663, 666-67 (1966).

46 The distinction between policy-making and non-policy-making employees is more fully discussed in the text at notes 104-107 infra.

47 A slightly different equal protection attack on patronage focuses both on the fact that patronage employees do not share the protections enjoyed by their merit system counterparts, and also that:

[a] statutory merit system is in a sense superfluous. By their own force, the first amendment and the concepts underlying "due process" and "equal protection" impose on government a requirement that public employment ... shall be made available to all persons fairly and reasonably. The implicit constitutional requirement for fair and reasonable distribution of government largesse is made explicit in a statutory merit system.

Schoen, Politics, Patronage, and the Constitution, 3 Ind. Legal F. 35, 81 (1969).

Still another aspect of the patronage employment system that arguably violates the Equal 


\section{Judicial Response to the Problem of Patronage Dismissais}

Challenges to dismissal from public employment are not new. 48 The courts, however, generally have refused to treat the patronage dismissal as a problem of free expression or equal protection. Their decisions instead either hold that the patronage employee has no constitutionally protected interest ${ }^{49}$ or conclude that whatever protection the first amendment affords against dismissal for reasons of political affiliation is waived by acceptance of a patronage job. ${ }^{50}$ Under both of these approaches dismissals are upheld without inquiry into the governmental interests served by patronage. Neither approach is convincing.

\section{A. "No Right to be a Policeman"}

Early public employment cases depended on the assertion that there is no right to public employment. Despite sweeping language that "the power of removal from office is incident to the power of appointment," "ø1 these early cases, without exception, involved dismissals for reasons unrelated to political affiliation; no unconstitutional conditions were imposed. ${ }^{\mathbf{2}}$

Protection Clause-the use of tax-paid patronage workers to perform valuable services for incumbent candidates, to the detriment of challenging candidates and their supporters -was at issue in Shakman v. Democratic Organization of Cook County, 435 F.2d 267 (7th Cir. 1970), cert. denied, 402 U.S. 909 (1971), modified on remand, 356 F. Supp. 1241 (N.D. IIl. 1972), and White v. Snear, 313 F. Supp. 1100 (E.D. Pa. 1970).

The Seventh Circuit in Shakman held unconstitutional the use of patronage to perpetuate the dominance of the party in power. On remand, the district court construed the decision as prohibiting "only political considerations which effect [sic] voter and candidate rights" (emphasis in the original), and relied on Bailey v. Richardson, 182 F.2d 46 (D.C. Cir. 1950), aff'd per curiam by an equally divided court, 341 U.S. 918 (1951), and Alomar v. Dwyer, 447 F.2d 482 (2d Cir. 1971), cert. denied, 408 U.S. 1020 (1972), in holding that "in all other respects patronage employees may be hired or fired based on political affiliation." $356 \mathrm{~F}$. Supp. at 1248. See discussion of Bailey and Alomar in text and notes at notes 58-71 infra. This construction was effectively overruled two months later in Illinois State Employees Union v. Lewis, 473 F.2d 561 (7th Cir. 1972), cert. denied, 410 U.S. 928, 943 (1973). See text and notes at notes 91-98 infra.

48 E.g., cases cited at notes 5I-53 infra; Perry v. Sindermann, 408 U.S. 593 (1972); Pickering v. Board of Educ., 391 U.S. 563 (1968); American Fed'n of State, County \& Municipal Employees v. Woodward, 406 F.2d 137 (8th Cir. 1969).

49 See, e.g., Alomar v. Dwyer, 447 F.2d 482 (2d Cir. 1971), cert. denied, 404 U.S. 1020 (1972); Indiana State Employees Assoc. v. Negley, 357 F. Supp. 38, 41-43 (S.D. Ind. 1973); Burns v. Elrod, No. 71 C 607 (N.D. Ill. May 31, 1972) (unreported); Moldawsky v. Lindsay, 341 F. Supp. 1393 (S.D.N.Y. 1972). See generally Young v. Coder, 346 F. Supp. 165 (M.D. Pa. 1972).

60 See discussion of American Fed'n of State, County \& Municipal Employees v. Shapp, 443 Pa. 527, 280 A.2d 375 (1971); text at notes $72-73$ infra.

61 Keim v. United States, 177 U.S. 290, 293 (1900).

52 In Crenshaw v. United States, 134 U.S. 99 (1890), a Naval Academy graduate was dis- 
The most quoted opinion supporting the "no right to public employment" analysis is McAuliffe $v$. Mayor of New Bedford, ${ }^{53}$ in which Justice Holmes wrote that " $[t]$ he petitioner may have a constitutional right to talk politics, but he has no right to be a policeman," 54 and thereby provided an easy escape from the delicate problems raised by dismissals from public employment for political reasons. The appeal of the epigram has obscured the sense of Holmes's reasoning, as revealed in the lines that follow the oft-quoted passage:

There are few employments for hire in which the servant does not agree to suspend his constitutional rights of free speech, as well as of idleness by the implied terms of his contract. The servant cannot complain, as he takes the employment on the terms which are offered him. On the same principle the city may impose any reasonable condition upon holding offices within its control..$^{55}$

In opposing the patronage system, a public employee does not assert a constitutional right to be hired, or even to be allowed full freedom of speech once hired; rather he asserts only a constitutional right to be evaluated without unreasonable reference to his political affiliation. The claim, then, is that the criterion of political affiliation violates Holmes's principle by imposing an unreasonable-and therefore unconstitutional-condition on holding a government job. The claim is thus a reflection of the principle of Perry v. Sindermann. ${ }^{56}$ Although the government has no affirmative duty to provide the benefit and the citizen has no constitutional right to receive the benefit, once the government has voluntarily committed itself to creating and distributing

charged from the service, there being no vacancies available for him to fill. In Ex parte Hennen, 38 U.S. (13 Pet.) 230 (1839), a district judge was held entitled to dismiss his admittedly faithful and competent clerk simply because he wanted to hire another friend to fill the post-no discriminatory basis was alleged. In Keim v. United States, 177 U.S. 290 (1900), the Supreme Court asserted its lack of supervisory power over matters of appointment and discharge committed to agency discretion. But there the plaintiff was removed for inefficient performance-an entirely permissible criterion to this day, even as concerns employees otherwise statutorily protected. Similarly, in Parsons v. United States, 167 U.S. 324 (1897), it was held that the President could remove a United States attorney when, in his discretion, he regarded it as for the public good; but nothing was said from which could be inferred any authority to discharge a public employee for a discriminatory reason bearing on that employee's exercise of his constitutional rights. See also Cafeteria \& Restaurant Workers v. McElroy, 367 U.S., 886, 896-99 (1961), involving a dismissal where no reason, rather than an impermissible reason, was given.

63155 Mass. 216, 29 N.E. 517 (1892).

54 Id. at 220,29 N.E. at 517.

55 Id. at 220, 29 N.E. at 517-18 (emphasis added).

66408 U.S. 593 (1972). See discussion in text and notes at notes 22-28 supra. 
such benefits, it is required to do so in a manner that does not infringe constitutional rights or punish their exercise. ${ }^{57}$

Holmes's reasoning surfaced decades later-without attribution-in Bailey v. Richardson, ${ }^{58}$ a public employment case that has been influential in patronage dismissal decisions. There the court announced:

the plain hard fact is that so far as the Constitution is concerned there is no prohibition against the dismissal of government employees because of their political beliefs, activities, or affiliations. That document, standing alone, does not prevent Republican Presidents from dismissing Democrats or Democratic Presidents from dismissing Republicans .... . The First Amendment guarantees free speech and assembly, but it does not guarantee government employ. ${ }^{69}$

This language would delight any advocate of patronage, yet an examination of its context reveals both that Bailey involved a fact situation distinctly different from the patronage dismissal, and that, although the Bailey facts justified dismissal, they did not warrant the sweeping language used by the Court.

Bailey involved a charge of disloyalty to the government and dismissal pursuant to an Executive Order ${ }^{60}$ specifying suspicion of disloyalty as a ground for denial of employment. No disloyalty to any political party was charged. The court reasoned that the government could regulate any act reasonably deemed to interfere with the efficiency of the public service: "A classification of loyal and disloyal [to the government] is undoubtedly a proper one descriptive of qualification and disqualification for public office."11 The concern in Bailey was with a nonpartisan threat of personal disloyalty (in an era of suspicion and defensiveness toward potential subversion) directly bearing on qualification for government employment. The case cannot be construed to hold that dismissal may be based on political affiliation because public employment is a privilege. ${ }^{62}$

67 Note, Unconstitutional Conditions, 73 HARv. L. REv. 1595, 1599 (1960). See also Keyishian v. Board of Regents, 385 U.S. 589 (1967) ("the theory that public employment which may be denied altogether may be subjected to any conditions, regardless of how unreasonable, has been uniformly rejected."); Torcaso v. Watkins, 367 U.S. 488, 495-96 (1961); Wieman v. Updegraff, 344 U.S. 183, 191 (1952).

58 I82 F.2d 46 (D.C. Cir. 1950), aff'd per curiam by an equally divided Court, 341 U.S. 918 (1951). Judge Edgerton, dissenting, recognized the majority's implicit deference to Holmes's "greatly oversimplified" statement in McAuliffe. $182 \mathrm{~F} .2 \mathrm{~d}$ at $71 \mathrm{n} .24$.

50182 F.2d at 59.

60 Exec. Order No. 9835, 12 Fed. Reg. 935 (1947), 5 U.S.C. § 631 (1952).

61182 F.2d at 61 .

02 The present law was correctly stated by Judge Edgerton in dissent: "Though members 
Nevertheless, Bailey has been cited as controlling in cases of purely partisan hiring and firing. ${ }^{63}$ For example, it was the sole authority cited in support of the Second Circuit's recent per curiam opinion in Alomar v. Dwyer. ${ }^{64}$ The trial court had granted summary judgment in favor of the city and political party officials alleged to have discharged a noncivil service employee solely because of her refusal to change party affiliation. The Second Circuit affirmed, holding that her non-civil service employment was "terminable at will without notice or hearing," regardless of any first amendment claim. ${ }^{65}$ "The Bailey court teaches that the sole protection for government employees who have been dismissed for political reasons must be found in civil service statutes or regulations." 68

Alomar, decided a year before Perry, did not anticipate the latter's important holding that even an employee whose job is terminable at will without notice or hearing may not be discharged because he chooses to exercise his first amendment rights. The Alomar court apparently believed that its denomination of public employment as a privilege rendered unnecessary any discussion of the strong public interests required to justify the revocation of even a privilege on political grounds. ${ }^{67}$

of minority parties have often been dismissed, in the past, to make room for members of a party in power, any comprehensive practice of that sort would today be unthinkable as well as illegal, and the Supreme Court has plainly indicated it would also be unconstitutional." $I d$. at 72.

63 See cases cited note 49 supra.

64447 F.2d 482 (2d Cir. 1971), cert. denied, 404 U.S. 1020 (1972).

65447 F.2d at 483, citing article 13, section 2 of the Constitution of the State of New York with regard to officers serving "during the pleasure of the authority making the appointment."

66447 F.2d at 483.

67 See note 5 supra. Alomar disclaimed any intention to hold that a provisional employee may be summarily discharged in all circumstances, noting that in some cases a discharge may involve more than "merely the loss of the privilege of public employment," including injury to reputation or impairment of eligibilty for other employment. 447 F.2d at 483 (citing Birnbaum v. Trussell, 371 F.2d 672 (2d Cir. 1966)). The observation is strikingly similar to the discussion in Roth of "liberty" interests in public jobs. See note 21 supra.

The Alomar court also seemed to find justification for its decision in the fact that the spoils system has been entrenched in American government since its inception, evidencing reluctance to extend civil service-type protection to positions that state and local legislative authorities have failed to accord such status. The court explicitly recognized the "devastating effect that [the spoils system] can wreak upon the orderly administration of government," but nevertheless felt compelled to conclude that "it is well understood that the victors will reap the harvest of those public positions still exempt from [civil service] laws." A similarly toned observation on the durability of the patronage system was made in American Fed'n of State, County \& Municipal Employees v. Shapp, $443 \mathrm{~Pa} .527,536$ note, 280 A.2d 375, 378 n.4(1971). 
The uncritical application of the Holmes epigram in the Bailey and Alomar opinions misses the basic constitutional objection to the patronage dismissal. ${ }^{68}$ Holmes's epigram is significant only insofar as it says that public employees "must comply with reasonable, lawful, and nondiscriminatory terms laid down by the proper authorities."69 As the Supreme Court has noted, constitutional protection does extend to public servants who are discriminatorily fired, regardless of whether some abstract right to public employment exists. ${ }^{70}$ To make the "facile generalization that there is no constitutionally protected right to public employment is to obscure the issue." 71 By resting on the fully discredited right-privilege distinction, the courts have failed to recognize the prima facie unconstitutionality of the patronage dismissal.

\section{B. The Waiver Theory-The "Political Sword" Approach}

Serious consideration of the constitutionality of patronage dismissals has also been short-circuited by the theory that acceptance of patronage employment constitutes a waiver of several constitutional rights. In American Federation of State, County o Municipal Employees $v$. Shapp, ${ }^{72}$ the Supreme Court of Pennsylvania tacitly relied on this rationale for its holding that patronage employees are not constitutionally protected against dismissal from their jobs. The court implied that any citizen who accepts a job under circumstances of political sponsorship is assumed to accept it with the knowledge that he will be discharged whenever his political views conflict with those of his superior. $\mathrm{He}$ is therefore deemed to have waived his constitutional right to object to a dismissal based on political affiliation. "Those who, figuratively speaking, live by the political sword," the court said, "must be prepared to die by the political sword."73 This justification of pa-

68 For examples of the courts' correct use of the Bailey dictum, 447 F.2d at 483, see Jensen v. Olson, 353 F.2d 825 (8th Cir. 1965); Norton v. Blaylock, 285 F. Supp 659 (1968), aff'd per curiam, 409 F.2d 722 (8th Cir. 1969). Norton concerned a welfare employee who was dismissed after notice and hearing on a charge that she had abused her position for personal ends; Jensen involved the dismissal of a municipal civil service employee for insubordination alleged to have disrupted his work and impaired the efficiency of his department. Reliance on Bailey in these cases shows by contrast its inapplicability to the patronage situation: neither Norton nor Jensen involved partisan dismissals; both concerned employees fired for nonpolitical reasons.

69 Slochower v. Board of Higher Educ., 350 U.S. 551,555 (1956).

70 Wieman v. Updegraff, 344 U.S. 183 (1952).

71 Id. at 191 .

72443 Pa. 527, 280 A.2d 375 (1971).

73 Id. at 529, 280 A.2d at 378 . The brief opinion in Shapp does not explicitly invoke the waiver concept, although it seems to be the source of the court's "political sword" metaphor. The opinion itself is framed in terms of the absence of a protected right-the Bailey line of reasoning. The waiver theory also received attention in Illinois State Employees 
tronage dismissals, though attractively simple, is both analytically and practically unsatisfying.

1. The Concept of Constitutional Waiver. Waiver of a constitutional right must be voluntary in the purest sense. ${ }^{74}$ It cannot be induced by apprehension of suffering some disadvantage or anticipation of gaining some benefit. ${ }^{75}$ This voluntariness requirement has profound roots in the very origin of the concept of constitutional rights. These rights are unalienable ${ }^{76}$ in a legal as well as philosophical sense.

Union v. Lewis, 473 F.2d at 573-74. See generally Note, 17 VILL. L. REv. 650, 765-66 (1972). Although it has not been widely employed, the theory merits consideration because of its apparent validity.

74 Because there can be no waiver where there is no constitutional right to waive, Justice Holmes, in McAuliffe v. Mayor of New Bedford, 155 Mass. 216, 220, 29 N.E. 517 (1892), was incorrect in likening the demands made of an employee by the government to those made by a private employer. Acceptance of a job from a private employer in no sense involves a waiver of rights, because the first amendment does not prohibit restrictions by private parties on free expression. Compare Lloyd Corp. v. Tanner, 407 U.S. 551, 567-68 (1972), with Amalgamated Food Employees Union v. Logan Valley Plaza, 391 U.S. 308, 315 (1968).

75 Cf. Miranda v. Arizona, 384 U.S. 486, 462 (1966); Malloy v. Hogan, 378 U.S. 1, 7 (1964); Bram v. United States, 168 U.S. 532, 542-43 (1897). Bram held involuntary a confession induced by an implicit promise of benefit to the accused; a waiver of the constitutional right against self-incrimination could not be so procured. Similarly, an induced waiver of first amendment rights cannot be considered voluntary. Recent developments in the field of plea bargaining suggest that, under extraordinary circumstances, the courts may find it necessary to relax this rigorous principle of constitutional voluntariness. See Santobello v. New York, 404 U.S. 257 (1971); North Carolina v. Pearce, 395 U.S. 711 (1969). Even if these cases do in fact modify the constitutional concept of voluntariness as applied to plea bargaining, there is no indication that this narrow deviation, very likely undertaken to avert the overwhelming practical problems that a pure voluntariness rule would cause in the criminal justice system, is intended to soften generally the waiver requirements for constitutional rights.

There may also be limits on the government's discretion to induce waiver of statutory rights by conditioning receipt of public benefits on such a waiver. For example, if receipt of Social Security benefits were conditioned upon a waiver of all future claims under the Federal Tort Claims Act, the classification thus created might raise equal protection problems. The limitations on this type of condition, however, would be much less severe than the voluntariness requirement for constitutional waiver. Some nonconstitutional waivers, such as waiver of a cause of action for damages against a private party, clearly need not be voluntary in the pure sense of "free from all inducement." The present discussion of waiver is confined strictly to the constitutional concept.

76 The conceptions of personal liberties that influenced the framers of the Constitution had their roots in seventeenth-century theories of property rights. See C. Macpherson, The Roots of Liberal-Democratic Theory 3 (1962). The concept of inalienability still finds its most common application in property law. See, e.g., Hayes v. Barringer, 168 F. 221, 224 (8th Cir. 1909). Although the framers did not explicitly describe as inalienable the personal liberties incorporated into the Constitution, the idea found expression at the Convention. Proposals were made providing that "[no] religious test or qualification shall ever be annexed to any oath of office under the authority of the United States." $M$. FARRAND, The Records of the Federal Convention 334, 342 (1911). Permitting public office thus to be conditioned on the surrender of religious freedom would have worked the same evil 
They cannot be sold by even the most willing seller. ${ }^{77}$ Because virtually all constitutional rights are entitlements against the government, the government is the only potential purchaser. Sensitivity to the possibility that the government might bargain for the surrender of constitutional rights, ${ }^{78}$ therefore, is intimately related to the concern that waivers of such rights be voluntary. ${ }^{79}$

Waiver of a constitutional right must be knowing as well as voluntary. The person whose waiver is sought must be fully aware of the consequences of his waiver. ${ }^{80}$ Waiver can be presumed only where it is clear that the individual has not only full knowledge of all the facts and of his rights, but also full appreciation of the legal effects of his acts. ${ }^{81}$ In Johnson v. Zerbst, the Court noted:

"courts indulge every reasonable presumption against waiver" of fundamental constitutional rights and ... we "do not presume acquiescence in the loss of fundamental rights." A waiver is ordinarily an intentional relinquishment or abandonment of a known right or privilege. The determination of whether there has been an intelligent waiver ... must depend, in each case, upon the particular facts and circumstances surrounding that case, including the background, experience, and conduct of the [maker of the alleged waiver]. ${ }^{82}$

The concern that a waiver be made with full awareness of its consequences is closely related to the requirement of voluntariness. Waiver of a constitutional right is, superficially at least, an irrational act, because it cannot be part of a bargained exchange that will benefit the

now caused by patronage. The form of alienation that most concerned the framers was expropriation by a sovereign unchecked by popular control. See G. WOOD, ThE CREATION OF THE AMERTCAN REPUBLIC 1776-1787 at 36-43 (1969). It is not difficult to perceive, however, that a sovereign armed with plenary powers to inflict large penalties and to control the dispensation of important public services and benefits could accomplish much the same result without illegitimate force.

Current legal usage indicates that denomination of certain rights as inalienable means that they cannot be bartered. See, e.g., BLACk's LAw Dictionary 903 (4th ed. 1957), Inalienable: "The characteristic of those things which cannot be bought or sold or transferred from one person to another, such as rivers and public highways, and certain personal rights; e.g., liberty."

77 See generally Calabresi \& Melamed, Property Rules, Liability Rules, and Inalienability: One View of the Cathedral, 85 HARv. L. REv. 1089, 1111-15 (1972).

78 See Note, Unconstitutional Conditions, supra note 14.

79 See note 75 supra.

80 Brady v. United States, 397 U.S. 742, 748 (1970).

81 Holland v. Boles, 225 F. Supp. 863 (N.D. W. Va. 1963).

82 Johnson v. Zerbst, 304 U.S. 458, 464 (1988), quoting from Aetna Ins. Co. v. Kennedy, 301 U.S. 389, 393 (1927), and Ohio Bell Tel. Co. v. Public Util. Comm'n, 301 U.S. 292, 307 (1937); Hodges v. Easton, 106 U.S. 408, 412 (1882). 
person whose waiver is sought in any immediately apparent way. The motivation for a waiver therefore must lie in subtler forms of selfinterest. For example, one accused of a crime can waive his protection against self-incrimination for the sake of expiation of guilt. ${ }^{83}$ One who could withhold information because of a privileged relationship can waive his right because he believes that to dény the information to someone else would be unfair. Because waiver is a form of behavior neither expected nor demanded by the legal system, ${ }^{84}$ it raises at least a suspicion of coercion and is not to be inferred without convincing evidence of the knowledge of the person who waives. ${ }^{85}$

2. Constitutional Waiver in the Patronage Context. The entire patronage process, from the campaign to the ouster of the patron's administration, is inconsistent with the concept of waiver of constitutional rights. First, it is not rational to believe that a waiver of the right not to be dismissed for political reasons is voluntary ${ }^{86} \mathrm{It}$ is possible, though unlikely, that the original political allegiance was not bought through promise of a patronage job. The giving of that allegiance may be voluntary, but it is not the right in question. The voluntary waiver in question regards dismissal, and it suggests that the employee wished to emulate the Egyptian slaves by being buried with his master. Voluntary submission to this fate is not consistent with human nature. It is possible that the employee recognized that he would lose office along with his patron and, in return for the benefits, resigned himself to the situation, but this is not a constitutionally voluntary waiver. Waiver cannot be inferred from the employee's recognition of the likelihood that his purely voluntary political preference will eventually be used to remove him from the ranks of those receiving government benefits. ${ }^{87}$

83 See Bram v. United States, 168 U.S. 532, 564 (1897).

84 See Holmes, The Path of the Law, 10 Harv. L. REv. 457, 459-64 (1897).

85 The concept that a patronage employee takes his job under an implied contract that the term of his employment will coincide with the term of the incumbent administration is similarly suspect. The implied-in-fact contract theory is really just a different conceptualization of the waiver theory. A finding of an implied-in-fact contract requires that the implicit obligations were intended by the parties. See 1 Winliston on ConTracrs, $\$ \S 3$, 90 (3d ed. 1957). Intent, in turn, is determined from the conduct of the parties and their experience in such affairs-the same factors looked to when determining the validity of a waiver. A theory of implied contract, then, supplies no shortcut to finding legally sufficient consent by large numbers of individuals.

so See note 75 supra.

87 When the citizen accepts a patronage job, it is substantially more likely than not that he is made aware of what he must do to retain his job. If he changes political affiliation during his sponsoring party's administration, he is almost certain to lose his job. The "waiver" thought to be implicit in his acceptance of his job, therefore, is really induced by an unambiguous threat. The patronage system is often defended, in fact, on the ground that it causes public employees to be more responsive by holding over them the threat of 
The unconstitutional condition analysis reflects this concept of voluntariness by prohibiting any inference of waiver of constitutional rights from the acceptance of a government benefit.

There are some situations, of course, where the government is permitted to condition employment on the employee's refraining from certain types of expression. The government can restrict expression by workers in security positions, for example, more than expression by workers in less sensitive jobs. ${ }^{88} \mathrm{~A}$ teacher can be dismissed without offending academic freedom if his freely exercised speech seriously impairs his performance as a teacher, his fitness for public service, or the school's operation. ${ }^{89}$ Government employees may be restrained from taking leadership of any partisan political movement. ${ }^{.0}$ In such cases there is a compelling governmental interest in the restriction of expression. These cases should be analyzed, however, as justified conditions. That such restrictions are found justified and the employee forced to take the job subject to those conditions does not imply that employees may be induced to waive their constitutional rights. Where receipt of a government benefit is conditioned on acceptance of an infringement of constitutional rights, the acceptance cannot be held to be a "knowing and voluntary waiver;" the condition must be independently justifiable or it must fall.

The ideas that there is no right to public employment and that constitutional rights are waived by acceptance of patronage employment are thus fundamentally at odds with present constitutional doctrine and the realities of the patronage system. The two theories do not justify stopping short of the inquiry into governmental interests that is dictated by the doctrine of unconstitutional conditions.

\section{The Unconstitutional Condition Approach: Illinois State Employees Union v. Lewis}

Illinois State Employees Union v. Lewi ${ }^{91}$ is without direct precedent in its holding that a patronage dismissal is prohibited by the first amendment. Although there have been federal and state decisions in other contexts upholding constitutional objections to dismissals of

dismissal. See text at notes 104-108 infra. Even if such a waiver were possible, it cannot be presumed that each of the 4,000 employees summarily dismissed in Lewis and Shapp accepted a patronage job with the degree of understanding required to make a waiver of the right not to be dismissed for political reasons a knowing waiver.

88 See, e.g., Cafeteria \& Restaurant Workers v. McElroy, 367 U.S. 886 (1961).

89 See, e.g., Pickering v. Board of Educ., 391 U.S. 563 (1968).

90 United States Civil Serv. Comm'n v. National Ass'n of Letter Carriers, 413 U.S. 548 (1978).

91473 F.2d 561 (7th Cir. 1972), cert. denied, 410 U.S. 928, 943 (1973). 
public employees, ${ }^{92}$ Lewis is the first case to apply the constitutional protection of political association to patronage employees.

In Lewis the court rejected arguments that the case presented a nonjusticiable political question, ${ }^{93}$ and that a decision for the employees would impose a civil service system upon the State of Illinois.94 Relying on Perry $v$. Sindermann and the other unconstitutional conditions cases, the court concluded that Alomar v. Dwyer was contrary to the "development of constitutional law subsequent to the Supreme Court's unequivocal repudiation of the line of cases ending with Bailey ... and Adler v. Board of Education, ${ }^{[05]}$... which [preceding doctrine] is now 'universally rejected." "96 The court stressed that the basic reasoning of Bailey was thoroughly undermined by Roth, which formally interred the right-privilege distinction as an implement of constitutional analysis. The state's reliance on Bailey and Alomar was therefore rejected.97

92 E.g., Pickering v. Board of Educ., 391 U.S. 563 (1968); United States v. Robel, 389 U.S. 258 (1967); Whitehill v. Elkins, 389 U.S. 54 (1967); Elfbrandt v. Russell, 384 U.S. 11 (1966); Shelton v. Tucker, 364 U.S. 479 (1960). See also cases cited in Perry v. Sindermann, 408 U.S. 593, 597 (1972).

93 Relying on the scope of the political question doctrine reviewed in Baker v. Carr, 369 U.S. 186, 208-37 (1962), Judge Stevens asserted no lack of judicially manageable standards for resolving the dispute or fashioning appropriate relief. As nonjusticiable "political questions" are, strictly defined, limited to disputes among the three federal branches, the doctrine is ordinarily inapplicable to the jurisdiction of the federal courts over state action which allegedly violates an individual's constitutional rights. See Shakman v. Democratic Organization of Cook County, 435 F.2d 267, 270-71 (7th Cir. 1970), cert. denied, 402 U.S. 909 (1971), modified on remand, 356 F. Supp. 1241 (N.D. Ill. 1972); White v. Snear, 313 F. Supp. 1100, 1102 (E.D. Pa. 1970).

94 Judge Stevens agreed that the state General Assembly had sole authority to fashion an employment code but denied that the effect of the court's decision would be to confer civil service tenure upon every state employee. Noting a distinct difference between a grant of tenure-which could not be conferred by judicial fiat and is not provided for by the fourteenth amendment-and the prohibition of discharges for specified impermissible rea. sons, the court held this federalism objection to be without merit. This point is further discussed in the text at note 130 infra.

95 342 U.S. 485 (1952). Adler held constitutional New York's Feinberg Law, which pro. vided that membership in any organization advocating unlawful overthrow of the govern. ment disqualified one from employment as a public school teacher. Justices Douglas and Black dissented on grounds that "[s]o long as [a teacher] is a law-abiding citizen, so long as her performance within the public school system meets professional standards, her private life, her political philosophy, her social creed should not be the cause of reprisals against her." 342 U.S. at 511. Adler was effectively overruled in Keyishian v. Board of Regents, 385 U.S. 589 (1967).

$96473 \mathrm{~F} .2 \mathrm{~d}$ at 568.

97 In dissent, Judge Kiley urged that the Roth footnote, 408 U.S. 564,572 n.9, was directed only toward the procedural due process aspect of the decision in Bailey, and that as to the first amendment "premise," Roth left Bailey intact. Regardless of which is the correct intexpretation of the current status of Bailey, Roth is irrelevant to the political affiliation issue in Lewis. See text at notes 18-22 supra.

A district court in Indiana, in refusing to grant a preliminary injunction restraining the 
In addition to rejecting the no-right-to-public-employment reasoning of Bailey and its progeny, Lewis rejected the waiver theory of Shapp. The court refused to adopt an assumption of waiver, and a factual basis for a finding of waiver was lacking because of the summary judgment below. The court intimated that had there been a factual record, it would have indulged every reasonable presumption against finding such mass waivers. The particular factual basis of a waiver defense, the court said, would necessarily vary among employees. ${ }^{88}$ Rejection of these two common justifications for the patronage dismissal led to the first judicial consideration of the public interests alleged to be served by the preservation of that practice.

\section{The Competing Interests}

\section{A. Standards of Evaluation}

It has been shown that the patronage dismissal restricts freedom of political association and discriminates among citizens on the basis of political affiliation. It is therefore unconstitutional unless the restrictions and discriminatory effects are outweighed by important governmental interests. A significant preliminary question is how important those competing interests must be in order to overcome the prima facie unconstitutionality of the patronage dismissal.

The requisite weight of governmental interests may differ according to the basis or the effect of the challenged acts. The basis question relates primarily to the potentially unequal protection of the laws caused by the patronage dismissal. In recent years, the Supreme Court has been inclined to require close scrutiny of governmental interests and a more compelling justification for a classification based on criteria that are deemed "suspect." Although such "suspect classifications" have traditionally involved criteria of race, religion, or heritage, there is some authority for the proposition that the range of suspect criteria is growing and now includes political affiliation. ${ }^{100}$

discharge of patronage workers, felt it unnecessary to follow Lewis, concluding "that the Seventh Circuit intended to limit Lewis to its facts," since it merely reversed an erroneous summary judgment. Indiana State Employees Assoc. v. Negley, 357 F. Supp. 38, 42 n.5 (S.D. Ind. 1973). The court preferred to follow the reasoning of Alomar, Shapp, and Bailey.

$98 \mathrm{Cf}$. note 87 supra.

99 See Williams v. Rhodes, 393 U.S. 23 (1968). See also id. at 39 (Douglas, J., concurring); Note, A Constitutional Analysis of the Spoils System-The Judiciary Visits Patronage Place, supra note 14, at 1347-48 (1972).

100 See Communist Party of Indiana v. Whitcomb, 94 S. Ct. 656 (1974); Williams v. Rhodes, 393 U.S. 23 (1968); text and notes at notes 29-37 supra.

Justice Harlan complained in his dissenting opinion in Shapiro v. Thompson, 394 U.S. $618,658-59(1969)$, that the list of suspect criteria seems to be growing to include classi- 
Even if political affiliation is not considered a suspect classification which would trigger the scrutiny of the compelling interest test, the effect of the government's action on fundamental interests clearly requires strict scrutiny of the governmental interests. In Williams $v$. Rhodes, Justice Black explicitly ruled that only a compelling interest could justify limitations on political association. ${ }^{101}$

A compelling countervailing government interest, therefore, is required in order to justify the use of an employee's political affiliation as a class distinction on which to base dismissal from government employment. A demonstration that an employee's political affiliation bears a rational relation to some reasonable, legitimate governmental interest is insufficient to overcome the prima facie unconstitutionality of the patronage dismissal. ${ }^{102}$ The final step in a constitutional examination of the patronage dismissal is careful examination of the competing interests asserted by the government and the relation between those interests and the challenged practice. Although the prima facie unconstitutionality of the practice has been demonstrated, it is far from

fications based upon the exercise of any constitutional right. He explicitly pointed to the fact that already the "criterion of political allegiance may have been added in Williams $v$. Rhodes...."

101393 U.S. 23, 31 (1968), citing NAACP v. Button, 371 U.S. 415, 438 (1963). It is instructive to note the variations among the Justices' opinions in Williams. Justice Douglas concurred with Justice Black's opinion but preferred to go further and employ the BlackDouglas absolutist view of the first amendment, quoting Justice Black to Justice Black: "it is unnecessary to decide whether Ohio has an interest, 'compelling' or not, in abridging those rights, because "the men who drafted our Bill of Rights did all the "balancing" that was to be done in this field.' Koningsberg v. State Bar, 366 U.S. 36, 61 (1961) (Black, J., dissenting)." 393 U.S. at 39-40. Justice Harlan, who later dissented in Shapiro v. Thompson, 394 U.S. 618, 655(1969), concurred only in the result, preferring to use the first amendment right of political association rather than unnecessarily draw upon the Equal Protection Clause. 393 U.S. at 41-48. Justice Stewart, dissenting, would have employed the milder "mere rationality" test to the state interest involved. Id. at 48-61.

102 There have been recent indications that the Supreme Court is moving toward a level of judicial scrutiny midway between the traditional minimal and strict levels. See, e.g., Frontiero v. Richardson, 411 U.S. 677 (1973); San Antonio Indep. School Distr. v. Rodriguez, 411 U.S. 1, 70 (1973) (Marshall, J., dissenting); Gunther, The Supreme Court, 1971 TermForeword, In Search of Evolving Doctrine on a Changing Court: A Model for a Newer Equal Protection, 86 HARv. L. Rev. 1 (1972). There has been no indication, however, that where a government action restricts freedom of speech or association in a manner that discriminates between political viewpoints, any middle standard of review is to be applied. See Communist Party of Indiana v. Whitcomb, 94 S. Ct. 656, 663 (1974) (Powell, J., concurring); Williams v. Rhodes, 393 U.S. 23 (1968). The only possible move toward a middle ground in first amendment cases occurred in United States Civil Service Comm'n v. National Ass'n of Letter Carriers, 413 U.S. 548 (1973), where, in upholding the Hatch Act's general prohibitions of political activity (not dependent-on political affiliation), Justice White spoke of governmental interests that are "obviously important," "fundamental," essential," and "critical." Id. at 564-65. The opinion, however, never specified one standard of review as proper. 
clear whether the interests asserted in defense of the patronage dismissal should be characterized as compelling. In making this evaluation, however, it must be recognized that a particular method of satisfying even a compelling governmental interest cannot be justified if another method, less restrictive of constitutional rights and equally effective in serving the governmental interest, is available. ${ }^{103}$

\section{B. The Need for Employee Loyalty-An Incomplete Justification}

Political loyalty of employees to their superiors is a legitimate legislative goal; it helps insure that the system of representative government is not undermined by obstructionist acts of out-party members. It is traditionally claimed that the patronage system guarantees both that subordinates will not attempt to discredit the party or sabotage its programs and that such employees will be more responsive to their superiors because they risk summary dismissal for insubordination.

This justification, however, is not without limitations, as the Lewis court expressly recognized. ${ }^{104}$ Plaintiffs there did not challenge the public executive's right to use political philosophy or affiliation as a criterion in selecting those employees who would make policy and other key decisions. Few people would question, for example, a governor's right to pick the members of his cabinet using political affiliation as an important criterion. Criteria such as political philosophy and party loyalty do not seem pertinent, however, for filling the positions of elevator operator, file clerk, janitor, or driver's license examiner. It is doubtful whether any political opinion of the individuals holding such jobs could interfere with the efficiency of the public service, ${ }^{105}$ because such employees can always be discharged for good cause. If an employee frustrates the execution of the policies of his politically adverse superior, discharge for insubordination does not violate his constitutional rights. ${ }^{106}$ The remainder of this discussion posits that personal loyalty is sufficient to justify political dismissals at the policy-making level, and that the patronage dismissal is unconstitutional only with regard to non-policy-making employees. ${ }^{107}$ As to those employees, however, pro-

103 See note 13 supra.

104473 F.2d at 574.

105 See Bailey v. Richardson, 182 F.2d 46, 72 (D.C. Cir. 1950) (Edgerton, J., dissenting).

106 See American Fed'n of State, County \& Minicipal Employees v. Shapp, 443 Pa. 527, 543, 280 A.2d 375, 382 (1971) (Barbieri, J., dissenting):

[W] functioning of government, those individual rights may be subordinated to the government interest, if, in the balance, the governmental interest requires greater protection. ... [But $t$ ] here can be no question that [non-policy-making and non-policyimplementing employees] may not be discharged for the patently arbitrary and discriminatory reason that they are or were members of the Republican party.

107 Id. at 535, 280 A.2d at 378; Mitchell v. Chester Housing Authority, 389 Pa. 314, 328, 
hibition of the discharge for political reasons would not deprive the government of the legitimate power of discipline it needs to insure orderly and efficient operations.

Even assuming there is a compelling interest in the loyalty of nonpolicy-making personnel to the incumbent as well as to the government in general, it is not clear that such an interest is better served by the patronage system than by a nonpatronage system. It may not be assumed that patronage employees are always significantly more loyal or responsive than their nonpatronage system counterparts. The spoils system operates under the rationale that the patron will award spoils to an individual who has given, or can give, something in return. What many patronage employees have to offer in return is votes-their own and those of friends and neighbors. ${ }^{108}$ They may be relatively powerful

132 A.2d 873,880 (1957). It should be noted, however, that judicial creation of a line between policy makers and non-policy makers will not be easy. See Illinois State Employees Union v. Lewis, 473 F.2d 561, 578 (Campbell, J., concurring); Gould v. Walker, 356 F. Supp. 421 (N.D. Ill. 1973). Perhaps the most that can be done initially is to set down the standards described in Shapp for generally classifying employees and await either case-by-case construction or a more precise employment classification scheme by the legislature. See P. DAvid \& R. Pol.rock, Executives for Government ch. 5 (1957).

It is perhaps instructive to note another view of the policy/non-policy classification in a related area of public employment. In United Public Workers v. Mitchell, 330 U.S. 75 (1947), the Supreme Court, in upholding the Hatch Act restrictions on active partisan activity by federal civil service employees, reasoned that the public interest in (I) not compromising the quality of the public service and (2) not permitting the use of public office for the advancement of partisan causes, justified these restrictions. The dissenters rejected these interests as insufficient justification. What is noteworthy for the patronage issue is that all of the Justices sitting agreed that public employees' interests in political action (and, a fortiori, in political affiliation) were protected by the first amendment; they disagreed only as to what justifications were sufficient to permit restriction of those interests. Consequently, while the majority felt that the Hatch Act restrictions could validly apply to all employees, Justice Douglas, in dissent, felt that there was no significant public interest requiring the political neutrality of postal clerks or subway conductors (whom he called "industrial employees"). Citing F. Morstein Marx, Public Management in the New Democracy 205-06 (1940), he noted that the typical industrial civil servant has no more opportunity to make policy than the ordinary citizen; his work, being wholly ministerial, is unaffected by his political views. Judge Stevens, in Lewis, and Justice Barbieri, dissenting in $S h a p p$, considered policy-making positions fair game for partisan restrictions; Justice Douglas's dissent drew the same line but held that the policy-making "administrative" employees should be of the most impeccable political neutrality so that no question of divergence between them and the executive could arise. While the ultimate aims are the same-to ensure responsiveness and harmony of action between policy makers and policy implementers and the elected representatives of the people-the perceptions of the means which are necessary to draw restrictions most narrowly so as to achieve those aims stand in ironic contrast. Douglas, Stevens, and Barbieri are agreed, however, on the point most relevant to this discussion-that any statute or policy which purports to justify the political sterilization of public employees must be narrowly drawn to restrain such conduct only where necessary to serve a substantial governmental interest.

108 See W. Rrordon, Plunkitt of Tammany Hall 11-16, 47 (1963). 
precinct captains or simply persons who can deliver thirty or forty votes. The patronage employee with a sizable number of votes under his control may be able to discriminate against particular party candidates and favor others, "sit out" the election, or leave the political arena for another job. The patron will be reluctant to fire someone if he risks losing a block of votes. In some situations a patronage employee may feel no more personal loyalty than a civil service employee with full procedural protection.

In light of such considerations, it appears difficult to prove that partisan loyalty is a compelling governmental interest with regard to nonpolicy-making personnel, or that there is a substantial relation between patronage dismissals and promotion of employee loyalty.

\section{The Need for Employee Responsibility-A Question of Merit}

A second common justification for patronage employment is that patronage makes employees highly responsible to the public since their patrons are directly answerable at the polls for the quality of public administration. This argument expresses a fear that, without patronage, the various levels of government in the United States "will unavoidably fall victim to a proliferating, unresponsive bureaucracy composed of unyielding and unimaginative civil servants exercising political power unchecked by political responsibility."109 This is an ironic objection since the major alternative, the civil service system, was first introduced to eliminate the inefficiency, extravagance, and periodic mass firings of the spoils system. ${ }^{110}$

There has been a significant amount of criticism, however, of the "human paperweights" who allegedly fill the ranks of the merit system. ${ }^{111}$ Insulation from the electorate allows even low level administrators to consider the bureaucracy's own vested interests (for example, regularity, routine, and avoiding reductions in appropriations) and to rely increasingly on the cult of expertise of the professional technocracy as interpreted by its authoritative organs and personalities. ${ }^{112}$ The

109 Schoen, supra note 47, at 84, citing L. Whrte \& T. SMrth, Polmrcs, and Public ServICE ch. 2 (1939). See generally L. WHITE \& T. SMrTH, supra, chs. 3-4.

110 See generally C. Fish, The Crvil. Service and The Patronage (1905); K. Hanslowe, The Emerging Law of Labor Relations in Public Employment 7 (1967); D. Rosenbloom, Federal Service AND the Construtution chs. 2, 3 (1971).

111 See generally sources cited at note 115 infra.

112 See E. Banfirld \& J. Wilson, Crry Polrrics 221 (1963). The authors continue:

An administrator, by claiming that the grounds of his decisions are "purely professional," may be able to resist the claims of those interest groups which, for one reason or another, it is convenient for him to resist, as well as the directions of his political superiors. It is possible, therefore, for a bureaucracy which establishes its "highly professional" character to liberate itself from any will except its own. 
merit system may create problems in government administration that rival the incompetence and waste allegedly encouraged by the patronage system. Nevertheless, merit systems have grown significantly in number and coverage since the origin of the civil service in the late nineteenth and early twentieth centuries. ${ }^{113}$ The courts, therefore, do not lack models to aid their determination of whether civil servants or patronage employees are more responsive to public needs, complaints, and criticisms. The comparison will not lend itself to very precise measurement, but the government's assertion that patronage dismissals are necessary to ensure responsible public employees can and must be examined-not only to determine whether "responsibility" qualifies as a compelling interest, but also to determine whether patronage and "responsibility" are so closely related that this interest cannot be served by an employment scheme that does not condition employment on particular political affiliation.

\section{Ensuring the Smooth Functioning of Government}

The need for employee loyalty and responsibility are only facets of the government's overall need for structures that carry out the functions of public administration effectively and efficiently. If this need is a compelling interest, the court must focus on what employment scheme best serves that interest. This is one of the most important questions that the judiciary must address in assessing the constitutionality of patronage dismissals, and it is perhaps also the most difficult to resolve. Not only are merit and patronage schemes difficult to compare in terms of effectiveness and efficiency, there is no consensus on just what government functions are. The question involves evaluation of sociological, economic, and political philosophies that form the diverse roots of the American political culture. Although the courts have not exhibited great reluctance to consider such broad questions, ${ }^{114}$ judges must exam-

Id. at 222. The judiciary, of course, will want to consider the persuasiveness of this criticism when the civil servants involved are not bank examiners and economists, but rather janitors and elevator operators. See also L. WHITE \& T. SMrrk, supra note 109.

113 Twenty-three states have civil service systems covering more than 50 percent of their employees. Every city of more than 500,000 and 95 percent of cities with 100,000 or more population also have some form of civil service. However, fewer than 5 percent of the nation's counties have such a system. UnIted States Commission on Civil Righrs, FOR ALL the People . . B By ALL the People 63-64 (1969), cited in Comment, The Civil ServiceCollective Bargaining Conflict in the Public Sector: Attempts at Reconciliation, $38 \mathrm{U}$. CHI. L. Rev. $826 \mathrm{n} .2$ (1971).

114 See, e.g., Roe v. Wade, 410 U.S. 113 (1973); Brown v. Board of Educ. 347 U.S. 483 (1954). 
ine and openly enunciate the assumptions about the role of government that they use in a constitutional examination of patronage dismissals. ${ }^{115}$

Opponents of patronage claim that the system is essentially one of organized bribery, "wholly at odds with the conception of democracy which says that decisions ought to be made on the basis of reasonable discussion about what the common good requires."116 They argue that using political affiliation as an employment criterion injects an element

115 Professors Banfield and Wilson assert that differing conceptions of politics and government largely account for the wide divergence in goals and methods of operation espoused by advocates of so-called "good government" and advocates of machine government. These differing views are characterized as the "middle-class ethos" and the "immigrant ethos." The former is said generally to favor nonpartisanship, efficiency, impartiality, honesty, rational planning, model legal codes, and the cooperative search for the concrete implications of a more or less objective interest of the community as a whole; the latter is said to be concerned more with the neighborhood or ward than with the city as a whole, and to be more interested in specific material benefits than in the efficiency and impartiality of local government. See E. BANField \& J. Wrison, supra note 112, at 40-46, 123, 329-30. See also selections collected in section 4 of URBAN Government (E. Banfield ed. 1961). These two conceptions imply different sets of institutional arrangements that attach different degrees of importance to various governmental functions.

Reformers attack machine government as apolitical, its role in providing for the public welfare being essentially a by-product of its self-concern in winning elections and distributing wealth and power. See E. Banfield \& J. Wilson, supra note 112, at 116; D. Brocan, POLITICS IN AMERIGA 123 (1954). Opponents of reform, on the other hand, claim that machine government not only serves many latent social functions, see E. BANFIELD \& J. WiLson, supra note 112, at 126-27; R. Merton, SOctal TheORY aNd Social Structure 71-81 (1957), but also serves the "political function" of government. While the middle-class ethos of "good government" posits an objective public interest and thus aims at filling only the government's "service function" of supplying the citizenry with "needed" goods and services, the immigrant ethos of machine government recognizes broad social cleavages and enduring conflicts among factional interests and thus attempts to fulfill the "political function" of managing such conflict. See E. BANFLELD \& J. Wuson, supra note 112, at 18.

It is very difficult to determine objectively which form of governmental organization is the most effective and efficient, in part because it is necessary to make basic assumptions as to what the government should be efficient in doing and to what ends it should be effective. The implications of a judicial finding that one form is to be preferred to the other is potentially far-reaching, perhaps to the extent of attaching constitutional significance to one ethos over the other. See generally City Polrrics aNd PuBLIC Policy (J. Wilson ed. 1968); V.O. Key, Politics, Parties and Pressure Grouts (1958); S. Lubell, The Future of American Politics (3d ed. 1965); M. Rorko, Boss (1971); L. White \& T. SMITH, supra note 109; Urban Government (E. Banfield ed. 1961); Couturier, Patronage v. Performance -The Balance Sheet of Civil Service Reform, Good Government (Fall, 1967); Douglas, Politics and Postmen, NEw Repubuic, July 14, 1952, at 4; Farley, Patronage and the New Deal, American Magazine 20 (Sept., 1938); Moynihan \& Wilson, Patronage in New York State, 1955-1959, 58 AM. Pol. ScI. REv. 286 (1964); T. Roosevelt, The Merit System Versus the Patronage System, 39 CENTURY MAGAZINE 628 (1889); Wilson, The Economics of Patronage, 69 J. PoL. Econ. 369 (1961); Wilson, The Bureaucracy Problem, Public INTfrest (Winter, 1967).

116 E. BANFIELD \& J. WILSON, supra note 112, at 125-26. 
of irrationality into public administration. The system's political biases can cause misallocation of service resources to politically effective but socially inefficient actions, especially when favors are done for particular politicians. The built-in turnover of personnel results in unnecessary training and transition costs, and the power afforded by control of patronage jobs impels creation of unnecessary positions. The merit system was intended to eliminate these inefficiencies from public administration. Opponents of patronage cite with approval the Pendleton Act of 1883 and the Hatch Act of 1939 which politically neutralized large numbers of federal employees and numerous "little Hatch Acts" which have played a similar role at local levels. The aim of these laws is to remove the public employee from politics, to make professional expertise the basis of employee selection, to require that the civil servant serve with equal loyalty whatever party is in power, and to facilitate the periodic shifts in control of the government from one party to another without the financial costs and disruptive effect of large-scale turnovers in subordinate administrative positions. ${ }^{117}$

Defenders of patronage, on the other hand, criticize "good government" as more concerned with how things are done than with what is done; at least one study has concluded that although reform cities are more successful in decentralizing and distributing power, machine cities are more adept at distributing material perquisites. ${ }^{118}$ Under "good government," distribution of small amounts of power to a large number of groups, such as middle-class-oriented media, civic associations, unions, and business groups, creates a situation where the government commands insufficient power to manage the many diverse and often conflicting interests that must be reconciled before any action can be taken. This situation may channel the government's efforts into uncontroversial actions that benefit a large segment of the population. The government may be able to build a freeway but unable to devote its funds to fixing the streets or the schools in an individual ward.119

117 V.O. KEY, supra note 115, at 388-89 (1958); Pollock, The Cost of the Patronage System, 189 Annals Amer. ACAd. of Pol. \& Soc. ScI. 29-34 (1937). The Supreme Court, approving the Fatch Act in United States Civil Service Comm'n v. National Ass'n of Letter Carriers, 413 U.S. 548, 566 (1973), noted that one of the important goals of the Act was to insure that "employment and advancement in the Government service not depend on political performance, and at the same time to make sure that Government employees would be free from pressure and from express or tacit invitation to vote in a certain way or perform political chores in order to curry favor with their superiors rather than to act out their own beliefs."

118 Greenstone \& Peterson, Reformers, Machines, and the War on Poverty, in Crry PoLrtics ANd PUblic Policy 267 (J. Wilson ed. 1968). See also discussion in note 115 supra.

119 E. BANFIELD \& J. Wilson, supra note 112, at 110. See also Martin, The Town That Tried "Good Government", in URBAN GovernMENT 224 (E. BANFIELD ed. 1961); Reichley, 
Thus the ineffectiveness caused by reform government's inability to reach many small-scale individual problems may outweigh its efficiencies in dealing with those problems it does address. ${ }^{120}$

Government agencies have taken over many of the social functions of the old political machine; much of what was formerly dispensed as patronage favors is now distributed as a matter of right. Two prominent commentators, ${ }^{121}$ however, reason that "good government" differs from machine government only in motives, not in effects. There is no convincing evidence that "good government" provides any more or better services at lower cost. Where waste and lack of coordination exist as a result of the machine's lack of technically trained supervisory personnel, they exist in reform government because of the very profusion of such personnel. The machine has a lower-class bias, but reform government has a middle-class bias. The political and governmental arrangements of "good government" tend to emphasize procedural matters (such as speed, simplicity, and impartiality) at the expense of substantive ones, and although the machine may favor certain groups, reform governments are often incapable of aggregating influence sufficient to carry out large-scale programs. ${ }^{122}$

It is not clear whether the need for effective government is better served by reform government's evenhandedness or by machine government's sensitivity to particular groups and ability to act on their behalf. Nor can it be determined with certainty whether the civil service "paperweights" of reform government or the untrained and oft-replaced employees of the machine are more inimical to efficient government. It is clear, however, that the patronage system is not an essential element of effective and efficient government.

\section{E. Patronage, Parties, and Democracy}

The preservation of a democratic republic is, without question, a legitimate and important public interest. The Constitution established that form of government, and individual constitutional rights depend in many ways on its survival. Defenders of the spoils system have traditionally asserted that patronage serves to promote representative democracy, warning of dire consequences to that institution should

Philadelphia: "Good Government" Leads to Moral Frustration, in id. at 291; Tugwell, LaGuardia: "Good Government" Can Be Mismanagement, in id. at 284.

120 E. BANFIELD \& J. WiLson, supra note 112, at 149.

121 Id. at $339-42$.

122 See Hawley, Gommunity Power and Urban Renewal Success, 68 AM. J. of Sociology 422 (1963); cf. Duggar, The Relation of Local Government Structure to Urban Renewal, 26 LAW \& CoNTEMP. Prob. 49 (1961). 
patronage be abolished..$^{123}$ Their argument is that the political structure of the United States is not based on the needs of people in general, but on a broad matrix of reciprocal obligations between politicians and particular people. ${ }^{124}$ The ability to dispense favors is seen as being at the core of political power: without "boodle" (such as patronage jobs), there is no incentive for people to join and remain loyal to political organizations; without loyal party workers, there can be no strong political organizations; without strong parties, the electoral process, and therefore representative democracy, is threatened.

This house-of-cards argument has been a traditional response to proposals for reform, and it seems to contain at least a few kernels of truth. Most Americans do not participate actively in politics. Apart from occasional bursts of participation on behalf of a particularly controversial cause, a class or ethnic interest, or a charismatic candidate, citizens have traditionally tolerated the often irrational and incompetent manner in which their governments are run. Both incumbent and challenging parties do find cadres of workers among the ranks of those depending upon the party for personal favor or livelihood.125 The concept that political parties may in fact gain support from their ability to reward the faithful, however, ignores the broader points that merit systems have not destroyed parties and that, although patronage-based parties may reflect traditional and long-enduring assumptions underlying American political institutions, they are not rooted in the Constitution.

In Williams $v$. Rhodes ${ }^{126}$ the Supreme Court recognized that promotion of a two party system is not a sufficiently compelling public interest to justify restriction of constitutional rights. The state of Ohio had effectively barred minority parties from the ballot and defended the action as strengthening the two party system and thereby encour-

123 Edward J. Flynn, a Bronx boss who helped elect and re-elect Franklin D. Roosevelt, described patronage as:

what keeps a political organization going. It is the "spoils system" in operation. But as we cannot have government without elections, elections without organizations, or organizations without a "spoils system" to keep them going, it is obviously more than a pat catch phrase. The "spoils system" is not new, nor was it invented by any political party in this country. Its origins go back into the reaches of antiquity. "To the victor belongs the spoils" has always been the axiom of war, whether between nations or between individuals. If it is immoral, then man is immoral.

E. FlynN, You're THE Boss 25 (1947). See also W. RioRDon, supra note 108, at 13; L. WhItE \& T. SMrth, supra note 109, at ch. 3.

124 See M. Tolchin \& S. Tolchin, supra note 7; Whyte, The Nature of Political Obligations, in Urban Government 175-80 (E. Banfield ed. 1961).

125 Although the out-party, unlike the incumbent party, cannot support its workers from the public treasury (or indirectly through salary assessments), it still commands the services of workers eager to share in the spoils of victory. "And the hungxy sometimes work harder than the well fed." V.O. KEY, supra note 115 , at 389.

126393 U.S. 23 (1968). 
aging compromise and stability. ${ }^{127}$ The Supreme Court held that, although the state's interest was legitimate, it did not justify the state's infringement of the right to vote and to associate freely for the purpose of political expression. The Supreme Court has "not hesitated to strike down an invidious classification even though it had history and tradition on its side." 128 It should therefore not be reluctant to conclude that mere political tradition is an insufficiently compelling interest to justify restriction of first amendment rights. ${ }^{129}$

A further objection to judicial abolition of patronage is based on the need to protect the federalism and separation of powers concepts set forth in the Constitution. This objection asserts that the elimination of patronage amounts to the imposition of a civil service system and must be left to the state legislative and executive branches. Abolition of the patronage dismissal, however, is not the equivalent of imposition of a civil service system. The government's ability to exercise reasonable control over its employees, even to the point of having employment discretionary with the appointing official, is unaffected by the abolition of patronage. ${ }^{130}$ Employees would still be vulnerable to discharge for good cause or even for no cause; the government would be restricted only to the extent that it would not be permitted to discharge public

127 Id. at $31-32$.

128 Levy v. Louisiana, 391 U.S. 68,77 (1968), citing Brown v. Board of Educ., 347 U.S. 483 (1954), and Harper v. Virginia Bd. of Elections, 383 U.S. 663, 669 (1966).

129 Some authorities counter the traditional floodgates defense of patronage by asserting that "advancing merit systems will not kill patronage before it withers and dies of its own infirmity and old age." Sorauf, The Silent Revolution in Patronage, 20 PuB. Admin. Rev. 28, 34 (1960). See also Sorauf, Patronage and Party, 3 MmWEst J. of PoL. Scr. 115-26 (1959). The parties are now generally left with less desirable, poorly paid positions to dispense. The public is less tolerant of political mediocrities in public service in the name of party loyalty; the public-spirited citizen is more admired than the self-interested party worker. Furthermore, the needs of modern party operations are different: radio and television are playing a growing role while the need for armies of patronage workers declines, and assessments on the salaries of patronage employees provide only a tiny fraction of the costs of campaigns. The inducements held out by the spoils system are becoming less attractive to the people who can make significant contributions to campaigns in terms of skill and funds. Prestige, power, and personal satisfaction, rather than jobs, are purportedly the incentives of the new political worker. Sorauf, The Silent Revolution in Patronage, supra at 33. If this view is correct, judicial review may be made unnecessary due to the early demise of the defendant.

Professor Sorauf's analysis allows the uncomfortable inference, however, that a change from the patronage system to the merit system will only signal the triumph of Banfield's "middle-class ethos," see note 115 supra, and the development of a new middle-class patronage dispensing prestige and power (in addition to the continuing forms of non-employment patronage which favor the middle and upper classes, see note 7 supra).

130 Illinois State Employees Union v. Lewis, 473 F.2d 561, 567-68 (7th Cir. 1972). 
employees for political affiliation. ${ }^{131}$ This represents neither a radical change in the law nor judicial legislation, but merely an application of a traditionally accepted constitutional doctrine.

\section{Gonclusion}

Serious constitutional objections have been raised to the practice of using political party affliation as a criterion for dismissing public employees who are unprotected by merit statutes. Thus far only one court has engaged in the kind of constitutional analysis generally used to evaluate the strength of prima facie cases of unconstitutionality-weighing the importance of the interests asserted by the government against the impairment of rights caused by the conditions placed on the receipt of public benefits. The other courts that have addressed the issue of patronage have been distracted by peripheral issues.

This discussion has emphasized that once an individual employee has established that a dismissal restricts his freedom of expression or association, a presumption of unconstitutionality arises that the government can rebut only by showing a compelling justification. The dismissed employee need not demonstrate that the government would operate better with a nonpatronage system than with a patronage system of employment. Even if the government is able to show some weaknesses in alternative systems and is able to prove that patronage is equally as effective a criterion for public employment, patronage dismissals would still be unconstitutional. The same would be true even if the government could prove that the patronage system is slightly superior to the alternative systems in serving governmental interests.

Only if the government proves that using the criterion of political affiliation is substantially more effective in serving compelling interests in efficient government is the burden of persuasion met. Neither appeals for the preservation of traditional political structures nor vague threats of dire consequences for the republic should persuade the courts to accept anything less than proof that the patronage dismissal is so integral a part of our political life and so far superior to any alternative mode of public personnel administration that its importance outweighs the impairment of free expression by public employees.

Glen S. Howard

131 A nonpatronage, non-civil service system might continue to allow some discrimination on the basis of political affiliation because an individual who is dismissed or fired for political affliation may have a difficult time proving a first amendment claim. Judicial action might be possible only where a mass action had taken place, as in Lewis and Shapp, or where a reason was expressly given, as in Alomar. For a discussion of the problems of proof in political favoritism, see note 7 supra. 